\title{
Study of Cytotoxic and Genotoxic Effects of Hydroxyl-Functionalized Multiwalled Carbon Nanotubes on Human Pulmonary Cells
}

\author{
Cinzia Lucia Ursini, ${ }^{1}$ Delia Cavallo, ${ }^{1}$ Anna Maria Fresegna, ${ }^{1}$ Aureliano Ciervo, ${ }^{1}$ \\ Raffaele Maiello, ${ }^{1}$ Stefano Casciardi, ${ }^{2}$ Francesca Tombolini, ${ }^{2}$ Giuliana Buresti, ${ }^{1}$ \\ and Sergio Iavicoli ${ }^{1}$
}

${ }^{1}$ Department of Occupational Medicine, Italian Workers' Compensation Authority (INAIL)-Research Area,
Via Fontana Candida 1, Monteporzio Catone, 00040 Rome, Italy
${ }^{2}$ Department of Occupational Hygiene, Italian Workers' Compensation Authority (INAIL)-Research Area,
Via Fontana Candida 1, Monteporzio Catone, 00040 Rome, Italy

Correspondence should be addressed to Cinzia Lucia Ursini, c.ursini@inail.it

Received 25 March 2012; Accepted 16 May 2012

Academic Editor: Paul A. Schulte

Copyright ( $\odot 2012$ Cinzia Lucia Ursini et al. This is an open access article distributed under the Creative Commons Attribution License, which permits unrestricted use, distribution, and reproduction in any medium, provided the original work is properly cited.

\begin{abstract}
Chemical functionalization of multiwalled carbon nanotubes (MWCNTs) increases their solubility, dispersion, and biological applications. Since there are only a few studies on the toxicity of functionalized MWCNTs, we investigated the cytotoxic and genotoxic-oxidative effects of OH-functionalized MWCNTs on human lung epithelial cells (A549) in order to obtain information on their biological effects. We exposed the cells to $10,20,40$, and $100 \mu \mathrm{g} / \mathrm{mL}$ of commercial MWCNT-OH for $24 \mathrm{~h}$. Cytotoxicity was then evaluated as the reduction in cell viability, membrane damage, and apoptosis, assessed by MTT and LDH assays and fluorescence microscopic analysis, respectively. The Fpg-modified comet assay was used to assess direct/oxidative DNA damage. We found a concentration-dependent reduction in cell viability and an increase of percentage of apoptotic cells, with no significant cellular LDH release. There was also concentration-dependent direct DNA damage but no oxidative DNA damage. These findings demonstrate the cytotoxicity of MWCNT-OH, through reduction of cell viability and induction of apoptosis without cell membrane damage, and the genotoxicity, by direct DNA damage induction, suggesting that the MWCNTs enter the cell without damaging its membrane and directly interact with the nucleus. This preliminary study highlights the need for further research to examine the potential toxicity of functionalized MWCNTs before starting to use them in biological applications.
\end{abstract}

\section{Introduction}

Carbon nanotubes (CNTs) have excellent potential applications in modern science and technology in the light of the unique chemical and physical characteristics resulting from their nanostructure [1]. Single-wall (SWCNTs) or multiwall (MWCNTs) carbon nanotubes are cylindrical and composed of carbon atoms. On account of their electrical, mechanical, and thermal properties, they are used in the automotive, aerospace, and computer industries, nanoelectronics, mechanical engineering, biomedicine, and cancer therapy. It has been predicted that tons of CNTs will be produced worldwide every year [2]. MWCNTs are produced by hightechnology laboratories but are also found in particulate matter from ordinary combustion of fuel gases [3].

Several studies have suggested the potential carcinogenesis of CNTs. Data obtained in the last few years on their toxicological effects are controversial: fiber length and diameter, surface area, tendency to agglomerate, dispersibility in media, impurities, and presence of metal catalysts due to the production method all influence their toxicity and reactivity [4-10]. Long-term exposure to SWCNTs can cause malignant transformation of human lung epithelial cells (BEAS-2B) with loss of contact inhibition, excessive 
cell growth, colony formation, increased cell migration, invasion, and angiogenesis [11]. Tumorigenicity in vivo after injection of such transformed cells into nude mice was also demonstrated [11].

Pristine CNTs are inert and insoluble in aqueous solutions, so in this form they cannot be used in many biological applications. However, to increase their solubility and dispersion they can be oxidized to obtain hydroxyl and carboxyl groups, particularly at the ends to which biomolecules or other nanomaterial can be added [12]. In general, chemical functionalization seems to modify the toxic effects; in particular, acid functionalization depletes metal residues, reducing the toxicity resulting from the presence of metal impurities of CNTs, but introducing functional groups could also raise the toxicity [13].

Most of the available studies on CNT toxicity have been performed on SWCNTs. In particular, in a study performed on human dermal fibroblasts exposed for $48 \mathrm{~h}$ to $3 \mu \mathrm{g} / \mathrm{mL}-30 \mathrm{mg} / \mathrm{mL}$ of SWCNT-phenyl-SO ${ }_{3} \mathrm{H}$, SWCNTphenyl- $\mathrm{SO}_{3} \mathrm{Na}$, SWCNT-phenyl- $(\mathrm{COOH})_{2}$, and underivatized SWCNTs stabilized in 1\% Pluronic F108, the authors found that as the degree of sidewall functionalization increased, the SWCNT sample became less cytotoxic [14]. Another study exposed epidermal keratinocytes to 0-0.05 mg/mL of 6-aminohexanoic-acid-derivatized SWCNTs (AHA-SWNTs) for $24 \mathrm{~h}$ to evaluate cytotoxicity by MTT assay. The study showed that the treatment with the surfactant 1\% Pluronic F127 caused dispersion of the AHASWNT aggregates in the culture medium and less toxicity in respect to AHA-SWNTs without surfactant treatment [15]. Dong et al. studied the influence of acid functionalization, obtained treating the SWCNTs with a mixture of concentrated $\mathrm{H}_{2} \mathrm{SO}_{4} / \mathrm{HNO}_{3}$, on SWCNT toxicity and the molecular toxic mechanisms of these acid functionalized SWCNTs (AFSWCNTs) in murine macrophages exposed for 24 hours to $0-50 \mu \mathrm{g} / \mathrm{mL}$ [13]. The global gene expression profiles showed that AF-SWCNTs penetrated the cell membrane and aggregated in the cytoplasm and nuclear areas, resulting in enhanced toxicity. AF-SWCNTs altered the expression of genes related to ribosomes, mitochondria, inflammatory response, cell cycle/apoptosis, and the proteasome pathway.

Amide-functionalized purified SWCNTs, obtained by reaction of SWCNT-COOH with dodecylamine, did not disturb the cell proliferation potential of harvested lymphocytes but induced more micronuclei than SWCNTs when used at a concentration of CNTs in dimethyl sulfoxide (DMSO) of $0.25-150 \mu \mathrm{L}$ per $5 \mathrm{~mL}$ of total cell culture volume, while normal human fibroblasts exposed to $0.5-30 \mu \mathrm{L} / \mathrm{mL}$ of amidefunctionalized SWCNTs showed double-strand DNA breaks, evaluated by counting $\gamma \mathrm{H} 2 \mathrm{AX}$ foci [16]. However, Albini et al. [17] showed that SWCNTs $1-5 \mu \mathrm{m}$ long, functionalized by oxidation obtained treating them with mixture of $\mathrm{H}_{2} \mathrm{SO}_{4}$ and $\mathrm{HNO}_{3}$ for 3 hours, had limited toxicity for endothelial cells exposed in vitro to $5,10,25$, or $50 \mu \mathrm{g} / \mathrm{mL}$, determined by growth, migration, morphogenesis, and survival assays; this suggested that these may be optimal vehicles for targeting the vasculature and potential carriers of antiangiogenic drugs.

An in vivo study on mice exposed to 10 or $40 \mu \mathrm{g}$ of AF-SWCNTs by intrapulmonary instillation reported that acid functionalization, performed suspending SWCNTs in $20 \mathrm{~mL}$ of $\mathrm{HNO}_{3} / \mathrm{H}_{2} \mathrm{SO}_{4}$ in $100 \mu \mathrm{L}$ high-pressure vessels in a microwave digester, increased cardiac ischemia/reperfusion injury and caused myocardial degeneration in mice [18].

Another study in mice exposed by oropharyngeal aspiration to acid-functionalized (obtained with the same treatment of the above-cited study) and pristine SWCNTs found that the former caused stronger pulmonary inflammation than pristine material, suggesting that either chemical modification of the nanotubes or the degree and type of dispersion affected their toxicity [19].

In mice exposed to pristine and oxidized SWCNTs by retrobulbar injection, a higher percentage of early miscarriages and fetal malformations were reported in animals exposed to oxidized SWCNTs at dose of $100 \mathrm{ng} / \mathrm{mouse}$ [20]. The same study also found extensive vascular lesions and increased production of reactive oxygen species (ROS) in placentas of malformed fetuses but not in normally developed ones.

Only a few studies have examined the biological effects of functionalized MWCNTs. Magrez et al. [21] showed that MWCNTs were more toxic in a human lung tumor cell line when carbonyl, carboxyl, and hydroxyl groups were used to functionalize them after acid treatment. In particular, they found in $\mathrm{H} 596$ cells grown in medium containing $0.02 \mu \mathrm{g} / \mathrm{mL}$ of functionalized MWCNTs a decrease of cell viability evaluated by MTT assay. Coccini et al. [22] highlighted that water solubility, high dispersibility, and low agglomeration tendency, resulting from chemical functionalization, had important effects on cytotoxicity. Patlolla et al. [23] observed that acid-functionalized MWCNTs, obtained refluxing purified MWCNTs with sulphuric/nitric acid, induced dosedependent membrane damage as $\mathrm{LDH}$ release, decrease of cell viability, increase of DNA damage, and apoptotic cell percentages evaluated on dermal fibroblast cells. In a further study on mouse bone marrow cells, obtained by mice intraperitoneally exposed to $0.25-0.75 \mathrm{mg} / \mathrm{Kg}$ of pristine and $\mathrm{COOH}$-functionalized MWCNTs (one dose for $24 \mathrm{~h}$ given for 5 days), MWCNT-COOH had higher clastogenic/genotoxic potential than nonfunctionalized MWCNTs [24].

The mechanism involved in the cellular uptake of shortened amino-functionalized (MWCNT-NH(3)(+)) was evaluated by $3 \mathrm{D}$ electron tomography on lung epithelial cells (A549) and primary macrophages exposed for 4 and $24 \mathrm{~h}$ to $50 \mu \mathrm{g} / \mathrm{mL}$ [25]. The tested MWCNTs were internalized in both kinds of cell by anyone of the following mechanisms: individually via membrane wrapping, individually by direct membrane translocation, and in clusters within vesicular compartments.

A recent in vivo study assessed the effects of functionalized MWCNTs $(\mathrm{COOH})$ in mice injected intraperitoneally with $0.25-0.75 \mathrm{mg} / \mathrm{Kg}$ of pristine and $\mathrm{COOH}$-functionalized MWCNTs (one dose for $24 \mathrm{~h}$ given for 5 days) using several hepatotoxicity and oxidative stress biomarkers [26]. After five-days exposure weight gain was reduced, there was ROS production, and the activities of serum aminotransferase (ALT/AST) and alkaline phosphatases (ALPs) and concentration of lipid hydroperoxide were higher than in controls. 
Our aim was to study the cytotoxic, apoptotic and genotoxic/oxidative effects of exposure to different concentrations of commercial hydroxyl-functionalized MWCNTs (MWCNT-OH) on human lung epithelial cells (A549) after detailed structural characterization of the CNTs by energyfiltered transmission electron microscopy (EFTEM). We chose a human alveolar epithelial cell line since lungs are the main potential target organ of exposure during manufacture and processing of nanomaterials [27-29] and SWCNTs and MWCNTs migrate into the alveolar interstitial compartment of the lung [30-32]. This experimental model was already used in an our recent study evaluating the cyto-genotoxicity of the same commercial MWCNTs in the pristine form, also after short exposures [33]. In that study we found an early loss of membrane integrity and genotoxic effects of the MWCNTs. The present study could provide further information about the potential toxic effects of functionalized commercial MWCNTs after $24 \mathrm{~h}$ exposure.

\section{Materials and Methods}

2.1. Transmission Electron Microscopy. MWCNTs were characterized using EFTEM. The nanotubes were dispersed in water, and the suspension was sonicated for 5 minutes. To measure the length of the nanotubes we deposited a drop of the nanotube suspension on 300 mesh copper grids with a carbon film. To gain details of the nanotube structural parameters, we also deposited a drop of suspension on 1000 mesh gold grids and acquired the images and spectra without the contribution of the carbon film. The nanotubes were located next to the gold wires or bridging them.

Conventional and high-resolution TEM (HRTEM) micrographs were acquired, and elemental analysis was carried out by energy-dispersive X-ray spectroscopy (EDS). Analysis using the copper grid coated with carbon film is less effective than HRTEM, but it enabled us to observe particles in the raw nanotube material.

TEM experiments were done using a FEI TECNAI 12 G2 Twin operated at an accelerating voltage of $120 \mathrm{kV}$, equipped with an electron energy filter (Gatan Image Filter, BioFilter model), a Peltier cooled charge-coupled device-based slowscan camera (Gatan multiscan camera, model 794IR), and an X-ray energy-dispersive spectrometer (EDAX Inc., model Genesis 4000).

2.2. Cell Culture. Human lung epithelial cell lines (A549) were obtained from the American Type Culture Collection (ATCC) (Rockville, MD) and cultured in RPMI 1640 (EuroClone, UK) supplemented with 10\% fetal calf serum at $37^{\circ} \mathrm{C}$ in $5 \% \mathrm{CO}_{2}$. Cells were seeded in $16 \mathrm{~mm}$ diameter culture dishes $\left(7 \times 10^{4}\right.$ cells/dish $)$ and cultured for $24 \mathrm{~h}$ before exposure. Cell cultures were exposed when semiconfluent.

2.3. Exposure. Commercial MWCNTs functionalized with a hydroxyl group $(\mathrm{OH})$ MWCNT-OH, provided by HeJi Inc (China), synthesized by chemical vapor deposition (CVD) were employed. Their purity was up to $97.37 \%$; the sample contained the following impurities: $\mathrm{Cl} 0.20 \%, \mathrm{Fe} 0.55 \%, \mathrm{Ni}$
$1.86 \%$, and S $0.02 \%$ (specifications given by the supplier). The functionalized nanotubes have $\mathrm{OH}>5 \%$ weight. A stock solution $(2 \mathrm{mg} / \mathrm{mL})$ of nanotubes suspended in distilled water was prepared. At the time for exposure the solution was vortexed $1 \mathrm{~min}$ then sonicated $5 \mathrm{~min}$ to disperse the structures. From this stock a working solution $(1 \mathrm{mg} / \mathrm{mL})$ of nanotubes was prepared in complete culture medium (RPMI 1640 ) and sonicated in two 5 min steps with a $30 \mathrm{sec}$ pause, then rapidly added to the cells to final concentrations of $10,20,40$ and $100 \mu \mathrm{g} / \mathrm{mL}$ (corresponding to $10,20,40$, and $100 \mu \mathrm{g} / \mathrm{cm}^{2}$ or to $2,4,8$, and $20 \mu \mathrm{g} / 10^{6}$ cells) of MWCNT$\mathrm{OH}$. Cells were kept at $37^{\circ} \mathrm{C}$ in $5 \% \mathrm{CO}_{2}$ during the exposure.

2.4. Cell Viability. The viability of A549 cells exposed for $24 \mathrm{~h}$ to MWCNT-OH was evaluated using the [3-(4,5dimethylthiazol-2-yl)-2,5-diphenyl tetrazolium bromide] (MTT) assay kit (Sigma Aldrich, USA). This colorimetric assay is designed for determining living cells as a function of mitochondrial activity. Briefly, after exposure, cells were washed with PBS to avoid any interference in light absorption due to the MWCNTs. Then, $500 \mu \mathrm{L}$ of fresh culture medium and $50 \mu \mathrm{L}$ of $5 \mathrm{mg} / \mathrm{mL}$ MTT solution were added to each well, and the cells were incubated for $3 \mathrm{~h}$ at $37^{\circ} \mathrm{C}$, protecting the plate from the light. The mitochondrial dehydrogenases of viable cells cleave the tetrazolium salt, yielding purple formazan crystals that are insoluble in aqueous media. At the end of incubation, the crystals were dissolved by adding $500 \mu \mathrm{L} /$ well of solubilization solution ( $10 \%$ Triton-X and $0.1 \mathrm{~N} \mathrm{HCl}$ in anhydrous isopropanol), and $200 \mu \mathrm{L}$ of final mixture was transferred to an optically clear 96-well flat-bottom microtiter plate. Absorbance was measured at $540 \mathrm{~nm}$ using a spectrophotometric microtiter plate reader (Wallac Victor2, Perkin Elmer, USA). The enzymatic activity directly correlates to the amount of formazan produced by reduction of the tetrazolium salt.

Background and negative controls were obtained by measuring the culture medium and untreated cell medium, respectively.

Data from control and treated cells were expressed as a percentage of viable cells [(enzyme activity of treated cells/enzyme activity of control cells) $* 100$ ], representing the mean of three separate experiments, using triplicate wells for each concentration.

Since nanomaterials could interfere with the MTT assay [34-36], we also did it after $30 \mathrm{~min}$ exposure to measure the absorbance of MWCNTs causing "false" cytotoxicity values. We washed the cells to remove all the nanotubes suspended in the medium and then ran the assay. After washing the cells, we thought that the best way to take into account the contribution of the unknown moiety of MWCNTs remaining on the cell membrane was to measure the "false" cytotoxicity at all the concentrations after $30 \mathrm{~min}$. The contribution of these values was taken into account to obtain the real data, adding the "false" percentage of cytotoxicity after 30 min of exposure to that of each experimental point.

2.5. Membrane Integrity. The lactate dehydrogenase (LDH) assay (ROCHE Diagnostics, Germany) is a colorimetric 
test for quantifying cytotoxicity, based on the measurement of $\mathrm{LDH}$ activity released from damaged cells into the supernatant. Briefly, after exposure, we removed $100 \mu \mathrm{L} /$ well of supernatant and transferred it into an optically clear 96well flat-bottom microplate; then we added $100 \mu \mathrm{L} /$ well of reaction mixture and incubated for $30 \mathrm{~min}$ at room temperature, protecting from light. We measured the absorbance of the samples at $490 \mathrm{~nm}$ using a spectrophotometric microtiter plate reader (Wallac Victor2, Perkin Elmer, USA). The percentage of cytotoxicity is calculated with the following equation:

$$
\left(\frac{\text { LDH activity of treated cells }}{\text { LDH activity of positive control }}\right) * 100 \text {. }
$$

We calculated the mean of three separate experiments, using triplicate wells for each concentration. Cells treated with Triton X-100 served as positive control.

2.6. Fluorescence Microscopic Analysis of Cell Death. Cells were seeded into $15.6 \mathrm{~mm}$ diameter culture dishes $(7 \times$ $10^{4}$ cells/dish) and cultured for $24 \mathrm{~h}$ before exposure. Semiconfluent cell cultures were exposed for $24 \mathrm{~h}$. After that they were washed with PBS and detached by trypsinization (0.25\% trypsin-0.04\% EDTA solution for endothelial cell culture, Sigma Aldrich, UK), centrifuged, washed once with PBS, and fixed with a solution of methanol/acetic acid (purity $99.90 \%$, Carlo Erba, Italy) $(3: 1 \mathrm{v} / \mathrm{v})$ for $30 \mathrm{~min}$. The cells were centrifuged, washed twice in PBS, incubated for $15 \mathrm{~min}$ at $37^{\circ} \mathrm{C}$ with $1 \mu \mathrm{g} / \mathrm{mL}$ Hoechst 33258 fluorescent dye (Boehringer Mannheim, Germany), dropped onto slides, and covered with a coverslip.

The cells were visualized to determine the nuclear chromatin morphology by fluorescence microscope (Leica) at 400x magnification. Apoptotic cells were recognized on the basis of nuclear condensation and/or fragmented chromatin. We counted apoptotic and normal cells. About 1000 cells from each slide were examined for apoptotic features by an experienced observer, and the percentage of apoptotic cells was calculated.

2.7. Comet Assay. After $24 \mathrm{~h}$ exposure the cells were washed with PBS then detached by trypsinization $(0.25 \%$ porcine trypsin in 2\% EDTA (Sigma-Aldrich, USA)), centrifuged, resuspended in $100 \mu \mathrm{L}$ of PBS, and immediately analyzed by the Fpg-modified comet assay, to evaluate the direct and oxidative DNA damage. We used the comet assay modified with the enzyme Fpg (Sigma Aldrich, USA), which recognizes and cuts the purine DNA bases indirectly allowing the detection of oxidative DNA damage [37]. Unexposed cells (treated only with suspension medium), were used as control. At least three independent experiments were run.

As described previously [35], with minor modifications, $90 \mu \mathrm{L}$ of normal-melting agarose (NMA) $1 \%$ in $\mathrm{PBS}$ at $50^{\circ} \mathrm{C}$ was layered onto gel bond film (Sigma, USA), immediately covered with a coverslip and left to solidify at $4^{\circ} \mathrm{C}$ for $5 \mathrm{~min}$. The coverslip, was then removed, and two gel bond films were prepared for each experimental point (one to be treated with Fpg enzyme and the other untreated), layering a mixture of about $30 \mu \mathrm{L}$ of cell suspension and $70 \mu \mathrm{L}$ of lowmelting agarose (LMA) $0.7 \%$ in PBS at $37^{\circ} \mathrm{C}$ on top of each film. A coverslip was added and the film was left to solidify at $4^{\circ} \mathrm{C}$ for $5 \mathrm{~min}$.

The coverslips were taken off and the films were layered on glasses and bathed in freshly prepared lysis solution (2.5 M NaCl, $100 \mathrm{mM} \mathrm{Na}_{2}$ EDTA, $10 \mathrm{mM}$ Tris with 1\% Triton $\mathrm{X}-100$, and $10 \%$ DMSO added fresh) in the dark for $1 \mathrm{~h}$ at $4^{\circ} \mathrm{C}$. The slides were removed from the lysing solution and washed three times in enzyme buffer $(40 \mathrm{mM}$ HEPES-KOH, $0.1 \mathrm{M} \mathrm{KCl}, 0.5 \mathrm{mM} \mathrm{Na}{ }_{2}$ EDTA, and $0.2 \mathrm{mg} / \mathrm{mL}$ bovine serum albumin, $\mathrm{pH} 8.0$ ), drained, and incubated with $50 \mu \mathrm{L}$ of either buffer or Fpg in enzyme buffer $(1 \mu \mathrm{g} / \mathrm{mL})$, in the dark for $30 \mathrm{~min}$ at $37^{\circ} \mathrm{C}$. The slides were placed in a horizontal gel electrophoresis tank filled with fresh alkaline buffer $(1 \mathrm{mM}$ $\mathrm{Na}_{2}$ EDTA and $300 \mathrm{mM} \mathrm{NaOH}, \mathrm{pH} 13$ ) for $40 \mathrm{~min}$ at $4^{\circ} \mathrm{C}$ to allow denaturing and unwinding of the DNA and the expression of alkali-labile sites.

Electrophoresis was done in the same buffer at $25 \mathrm{~V}$ and $300 \mathrm{~mA}$ for $30 \mathrm{~min}$ to allow the damaged DNA or fragments to migrate towards the anode. The slides were then washed three times with Tris $\mathrm{HCl} 0.4 \mathrm{M}$ for $5 \mathrm{~min}$ and stained with $50 \mu \mathrm{L}$ ethidium bromide $(20 \mu \mathrm{g} / \mathrm{mL})$. Slides were examined at 200X magnification under a fluorescence microscope. An undamaged cell appeared as a nucleoid and a cell with damaged DNA as a "comet." The slides were examined for severe genotoxicity before comet analysis, and "cloud" images were excluded. However, at the used exposure conditions, the percentage of clouds was always very low. Images of 50 randomly selected comets either from Fpgenzyme-treated or untreated slides, stained with ethidium bromide, were acquired and analyzed from each sample, with specific image analyzer software (Delta Sistemi, Rome, Italy).

Measurements of comet assay parameters such as the percentage of DNA in the tail (tail DNA\%), tail length, and tail moment (TM) representing the product of relative tail fluorescence intensity and length, were obtained from the analysis. For each experimental point, we calculated the mean TM of 50 comets from enzyme-untreated cells, which indicates direct DNA damage, and the tail moment of 50 comets from enzyme-treated cells (TM enz) evaluating direct and oxidative DNA damage. Oxidative DNA damage was evaluated in terms of oxidized DNA bases (sites recognized and cut by Fpg) and calculated by deducting TM from the TM enz, in exposed and unexposed cells (used as control).

2.8. Statistical Methods. Direct and oxidative DNA damage was assessed by comparing the mean TM and mean TM difference (TMenz-TM), respectively, of exposed and unexposed cells (as control) using a nonparametric KruskalWallis test followed by post hoc T3 Dunnett's and Bonferroni tests, and the significance of the difference was established for each experimental point. The nonparametric Kruskal-Wallis test followed by post-hoc T3 Dunnett's tests was also used to establish any significant differences between exposed and control cells for cell viability and apoptosis. 


\section{Results}

3.1. Particle Characterization. Characterization of the structural parameters by TEM indicated that they were "bamboolike," with no defined inner channel. Their outside diameter too was not well defined and changed abruptly along the nanotube itself.

Figure 1 shows micrographs and an EDS spectrum for $\mathrm{OH}$-functionalized MWCNTs. Figure 1(a) reports a typical TEM image used to assess the nanotube length, which varied from $20 \mathrm{~nm}$ to a maximum of $1.7 \mu \mathrm{m}$. It is also evident how difficult was to disentangle carbon nanotubes when dispersed in water. The minimum value of the tube length has an indicative meaning because nanotubes tended to break along their length, forming carbonious agglomerates of nanoparticles.

Figure 1(b) shows one of the TEM images used to measure the outside nanotube diameter, ranging from $10 \mathrm{~nm}$ up to $60 \mathrm{~nm}$, with a mean of $18 \pm 1 \mathrm{~nm}$ evaluated on 100 nanotubes. Figure 1(c) gives an example of a HRTEM image that clearly shows a MWCNT-OH ending with a particle inclusion. The EDS spectrum on this particle is reported in Figure 1(d), and elemental analysis revealed the presence of nickel, which is the metal catalyst used during synthesis.

3.2. Viability and Membrane Integrity. Cell viability was analyzed with MTT assay to determine mitochondrial metabolism. MWCNT-OH exposure induced a concentrationdependent reduction in viability compared to unexposed cells becoming significant from $20 \mu \mathrm{g} / \mathrm{mL}$ (Figure 2). The LDH assay did not show any significant percentages of cells with damaged membrane at the concentrations tested.

\subsection{Fluorescence Microscopic Analysis of Cell Death. To} evaluate the induction of apoptosis, we used Hoechst 33258 fluorescent dye, which binds to nuclear DNA, with intense fluorescence in cells that undergo apoptosis. Apoptotic cell death is characterized by chromatin condensation and/or nuclear fragmentation. Microscopic morphological analysis of treated A549 cells showed at each experimental point a significantly higher percentage of apoptotic cells than in unexposed cells, with a concentration-dependent pattern (Figure 3).

3.4. Comet Assay. MWCNT-OH exposure induced statistically significant increases of TM compared to the unexposed cells at all concentrations with a concentration-dependent trend (Figure 4). There were no differences between exposed and control cells, at any concentration, in oxidative DNA damage, evaluated by subtracting the mean TM of Fpguntreated cells from Fpg-treated cells (TM enz) (Figure 4).

\section{Discussion and Conclusions}

Although numerous recent studies have focused on the biological effects of CNTs, it is still not clear how functionalization influences their toxicity, particularly functionalized MWCNTs for which only very few studies are available. Most studies of the biological effects of functionalized CNTs used carboxylic acid-functionalized SWCNTs (COOH-SWCNTs) and amide-functionalized SWCNTs $[13,16,19,35,38]$. Some found that acid-functionalized SWCNT exerted stronger toxic effects in vitro, such as cytotoxicity, cell cycling inhibition, and apoptosis, and in vivo in comparison to unmodified SWCNT and that these effects could be reversed by neutralizing their negative surface charge [19]. In other investigations, exposure to $\mathrm{COOH}-\mathrm{SWCNT}$ at concentrations between 5 and $1000 \mu \mathrm{g} / \mathrm{mL}$ of CNTs for $24 \mathrm{~h}$ induced cytotoxic effects mainly at concentrations higher than $100 \mu \mathrm{g} / \mathrm{mL}$ on differentiated and nondifferentiated Caco-2 cells derived from a human intestinal adenocarcinoma [38].

The present study used a particularly suitable cell line to study the in vitro effects of commercial MWCNT-OH on the lung, one of the main target organs of CNTs. We found that $24 \mathrm{~h}$ exposure to functionalized CNTs reduced cell viability but not $\mathrm{LDH}$ release, indicating there was no membrane damage. Apoptosis was induced at all the concentrations, in agreement with the reduction in viability, suggesting that the reduction resulted from the induction of programmed cell death. We also noted a concentration-dependent increase in the DNA damage, demonstrating that MWCNT-OH can induce double- and single-strand DNA breaks even at the lowest concentration. The Fpg-comet assay allowed us to demonstrate that the MWCNT-OH used was not able to induce oxidative DNA damage.

Our previous study [33] using pristine MWCNTs showed, in the same exposure conditions (10, 40, and $100 \mu \mathrm{g} / \mathrm{mL}$ for $24 \mathrm{~h}$ ), a reduction in cell viability similar to that found in the present study. Pristine MWCNTs also induced $\mathrm{LDH}$ release, differently from MWCNT-OH, suggesting the two kinds of MWCNT have different mechanisms of cell penetration.

The differences in the cytotoxic effects in our two studies might be due not only to the $\mathrm{OH}$ group on the surface of MWCNTs but also to the shorter length and smaller diameter of MWCNT-OH than pristine MWCNTs, as demonstrated by TEM. The lack of cell membrane damage of MWCNT-OH in the present study, compared to the damage observed in our previous study on pristine MWCNTs might be due to the smaller dimensions, higher solubility, and weaker tendency to aggregation of MWCNT-OH.

Regarding genotoxicity, the present study demonstrates also for MWCNT-OH a direct, but not oxidative, DNA damage, as observed in our previous study on pristine form.

Among the few studies on functionalized MWCNTs, our results are in agreement with Patlolla et al. [23] who studied functionalized MWCNT-COOH toxicity due to exposure to 40,200 and $400 \mu \mathrm{g} / \mathrm{mL}$ in human dermal fibroblast cells, evaluating the cytotoxic response, DNA damage, and apoptosis; MWCNT-COOH exposure induced a dose-dependent decrease in cell viability starting from $40 \mu \mathrm{g} / \mathrm{mL}$, DNA damage in the comet assay, and induction of apoptosis after $48 \mathrm{~h}$ exposure. We found that even after shorter exposure $(24 \mathrm{~h})$ and with lower concentrations of functionalized MWCNTs than in Patholla's study, significant cytotoxicity and genotoxicity were induced, although we used another kind of chemical group $(\mathrm{OH})$ instead of $\mathrm{COOH}$ and a 


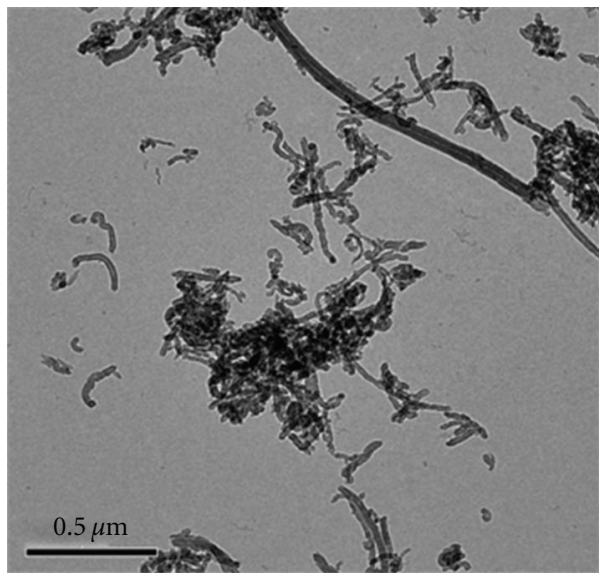

(a)

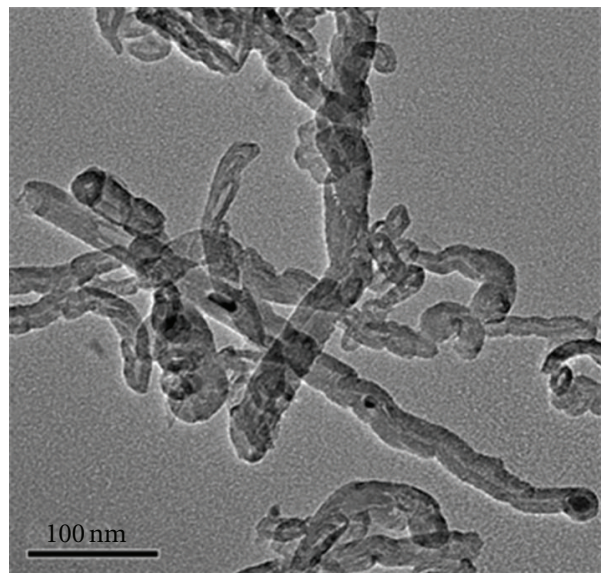

(b)

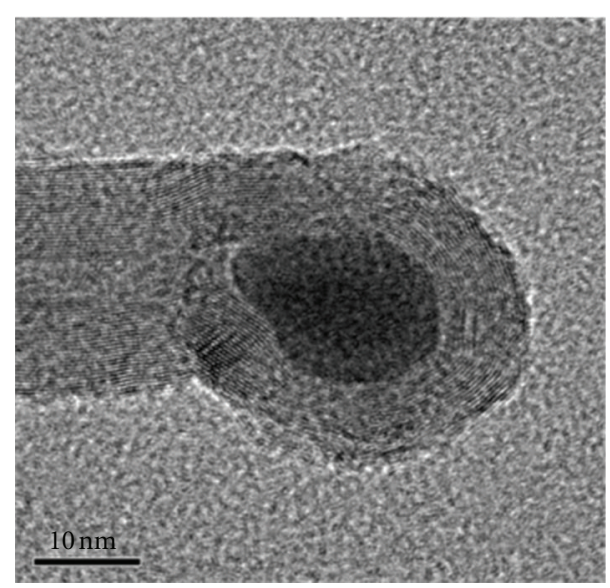

(c)

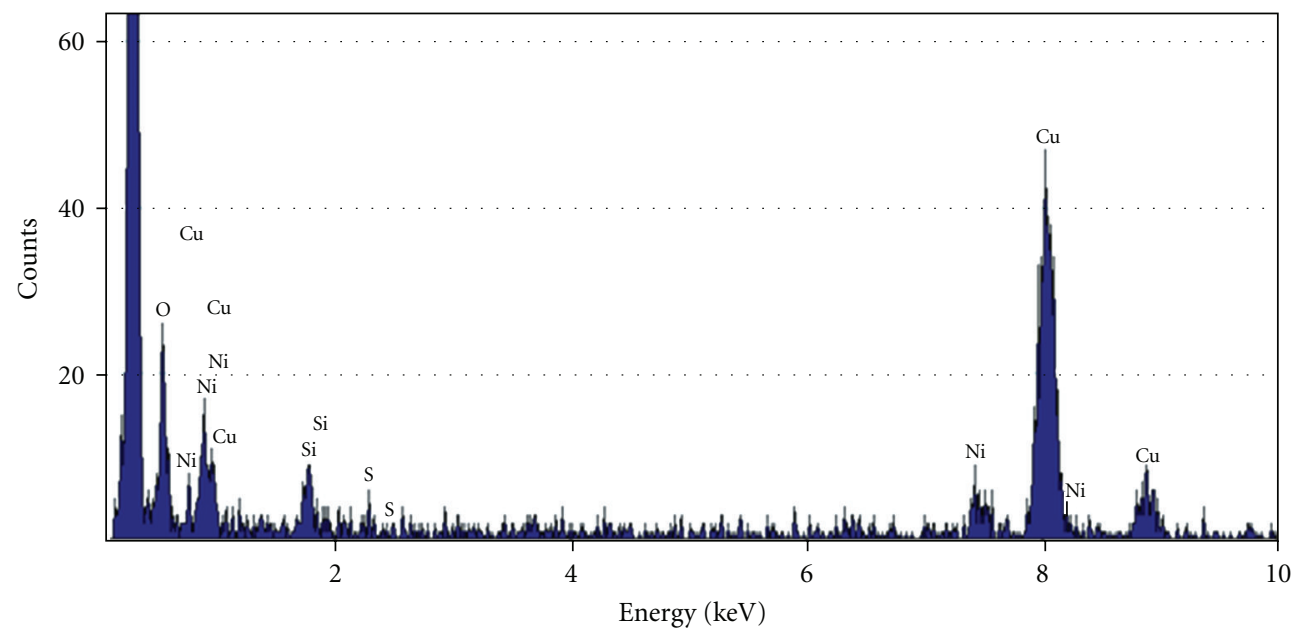

(d)

FIGURE 1: TEM images and EDS spectrum of $\mathrm{OH}$-functionalized MWCNTs deposited on a $\mathrm{Cu}$ grid coated with carbon film: micrographs acquired to measure (a) tube lengths (Bar $0.5 \mu \mathrm{m}$ ) and (b) the outside diameters (Bar $100 \mathrm{~nm}$ ); (c) high-resolution TEM image to evidence a particle of the metallic catalyst used to synthesize the nanotubes $($ bar $10 \mathrm{~nm}$ ) and $(\mathrm{d})$ the corresponding EDS spectrum. 


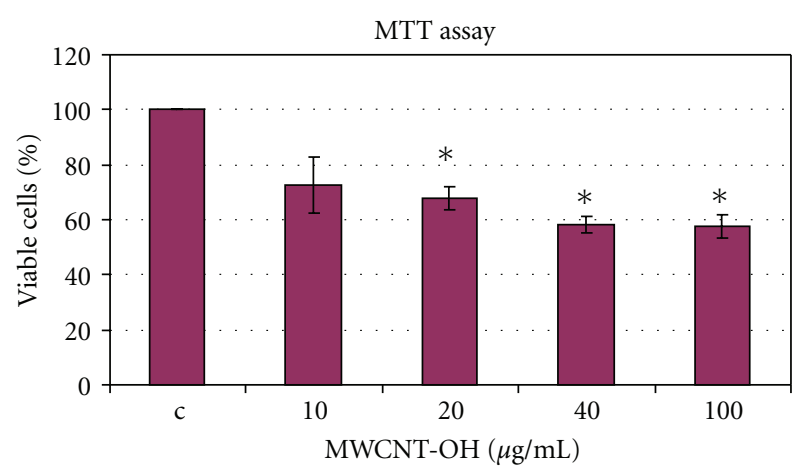

FIGURE 2: Viability of A549 cells after $24 \mathrm{~h}$ exposure to 10, 20, 40, and $100 \mu \mathrm{g} / \mathrm{mL}$ of MWCNT-OH evaluated by MTT assay. The data represent the mean of three separate experiments. The statistical significance of differences between exposed and unexposed cells was calculated by non parametric Kruskal-Wallis test followed by posthoc T3 Dunnett's test. ${ }^{*} P<0.05$.

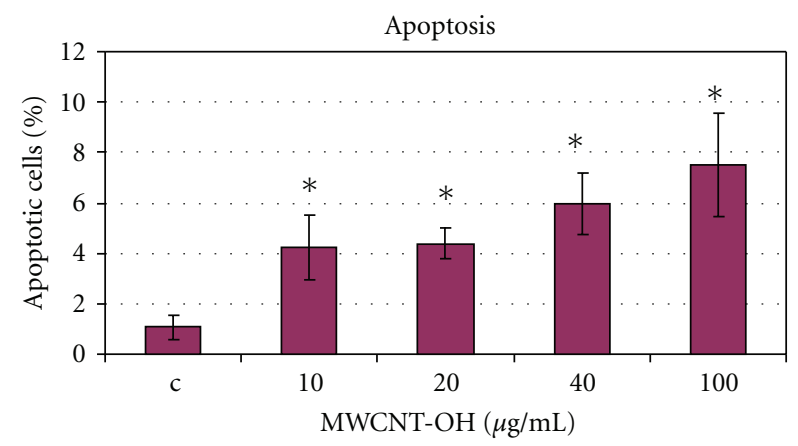

Figure 3: Apoptosis evaluation of A549 cells after $24 \mathrm{~h}$ exposure to $10,20,40$, and $100 \mu \mathrm{g} / \mathrm{mL}$ of MWCNT-OH. The data represent the mean of three separate experiments. The statistical significance of differences between exposed and unexposed cells was calculated by nonparametric Kruskal-Wallis test followed by post hoc T3 Dunnett's test. ${ }^{*} P<0.05$.

different cell model. Since we did not detect any oxidative DNA damage, the direct DNA damage might be the result of direct contact of MWCNT-OH with DNA, as suggested by Pantarotto et al. [39], who demonstrated that aminofunctionalized SWCNTs at concentration up to $10 \mu \mathrm{M}$ can cross the cell membrane and penetrate the nucleus through nucleopores. Shortened amino-functionalized MWCNTs can be internalized by A549 cells individually by membrane wrapping, direct membrane translocation, and in clusters within vesicular compartments [25]. Therefore, the lack of LDH release in our study might be explained by these suggested mechanisms, without damaging the cell membrane.

Bottini et al., [12], using lymphocytes, showed that $400 \mu \mathrm{g} / \mathrm{mL}$ of oxidized MWCNTs significantly reduced viability after $48 \mathrm{~h}$ of exposure, whereas we found earlier and higher toxicity for MWCNT-OH on lung cells. This might be explained not only by the different cell system but also by the different physicochemical features of the used commercial MWCNTs. Coccini et al. reported moderate

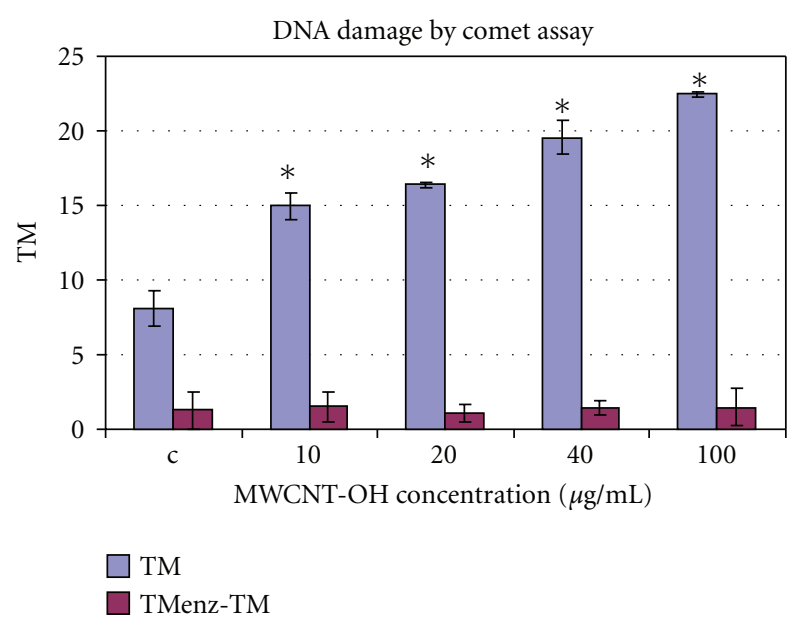

FIGURE 4: Effects of $24 \mathrm{~h}$ exposure to $10,20,40$, and $100 \mu \mathrm{g} / \mathrm{mL}$ of MWCNT-OH on A549 cells evaluated by Fpg-comet test. The histograms are related to the mean values of Tail moment (TM). Direct DNA damage is represented by mean TM value of cells untreated with Fpg enzyme. Oxidative DNA damage was evaluated subtracting TM mean values of cells untreated with Fpg enzyme (TM) from TM mean values of enzyme treated cells (TMenz) and is represented by TMenz-TM. The data represent the mean of three separate experiments. The statistical significance of differences between exposed and unexposed cells was calculated by non parametric Kruskal-Wallis test followed by post hoc T3 Dunnett's test. ${ }^{*} P<0.05$.

loss of cell viability for highly functionalized $\mathrm{MW}-\mathrm{NH}_{2}$ at doses $\geq 100 \mu \mathrm{g} / \mathrm{mL}$ and no loss of cell viability for less functionalized CNTs (MW-COOH and MW-NH2) on A549 and D384 astrocytoma cells [22].

Our results indicate that MWCNT-OH can induce apoptosis even at a low concentration $(10 \mu \mathrm{g} / \mathrm{mL})$ after $24 \mathrm{~h}$ of exposure, confirming the findings of Patlolla et al. [23], who showed a dose-dependent increase in the percentage of apoptotic cells after $48 \mathrm{~h}$ of exposure to MWCNT-COOH, starting from $40 \mu \mathrm{g} / \mathrm{mL}$. The present study demonstrates that MWCNT-OH can induce apoptosis on A549 cells at low concentrations, already from $24 \mathrm{~h}$.

Our study is particularly interesting since it simultaneously examines the cytotoxicity and genotoxicity of MWCNT-OH at relatively low concentrations on lung epithelial cells and represents one of the few that assesses the toxicity of functionalized MWCNTs which, until now, have been studied mainly in the $\mathrm{COOH}$-functionalized form. Since occupational exposure to these nanomaterials is increasing and studies are still so limited, this investigation provides useful information about the toxic effects induced by functionalized commercial MWCNTs. In particular, our demonstration of the cyto-genotoxicity of MWCNT-OH by DNA damage and induction of apoptosis highlights the need for further studies with multiple endpoints, in more biological systems, and at lower concentrations, to assess the potential toxicity of functionalized CNTs before starting to produce them in large amounts for their various applications, particularly in the biomedical field. 


\section{Acknowledgments}

This work was supported by funds from the Italian Ministry of Health for the project "P1: Innovative methodologies for risk assessment by occupational exposure to nanomaterials; Strategic Program Environment and Health (2006)." The authors are grateful to Dr. Stefano Bellucci (INFN, NLF, Frascati, Rome, Italy) who kindly supplied the functionalized MWCNTs.

\section{References}

[1] M. Endo, M. S. Strano, and P. M. Ajayan, "Potential applications of carbon nanotubes," Carbon Nanotubes, vol. 111, pp. 13-62, 2008.

[2] A. D. Maynard, R. J. Aitken, T. Butz et al., "Safe handling of nanotechnology," Nature, vol. 444, no. 7117, pp. 267-269, 2006.

[3] L. E. Murr, J. J. Bang, P. A. Guerrero, D. A. Lopez, and E. V. Esquivel, "Carbon nanotubes, nanocrystal forms, and complex nanoparticle aggregates in common fuel-gas combustion sources and the ambient air," Journal of Nanoparticle Research, vol. 6, no. 2-3, pp. 241-251, 2004.

[4] K. Donaldson, R. Aitken, L. Tran et al., "Carbon nanotubes: a review of their properties in relation to pulmonary toxicology and workplace safety," Toxicological Sciences, vol. 92, no. 1, pp. 5-22, 2006.

[5] E. Herzog, A. Casey, F. M. Lyng, G. Chambers, H. J. Byrne, and M. Davoren, "A new approach to the toxicity testing of carbon-based nanomaterials-the clonogenic assay," Toxicology Letters, vol. 174, no. 1-3, pp. 49-60, 2007.

[6] A. Nel, T. Xia, L. Mädler, and N. Li, "Toxic potential of materials at the nanolevel," Science, vol. 311, no. 5761, pp. 622627, 2006.

[7] A. A. Shvedova, E. R. Kisin, D. Porter et al., "Mechanisms of pulmonary toxicity and medical applications of carbon nanotubes: two faces of Janus?" Pharmacology and Therapeutics, vol. 121, no. 2, pp. 192-204, 2009.

[8] P. P. Simeonova, "Update on carbon nanotube toxicity," Nanomedicine, vol. 4, no. 4, pp. 373-375, 2009.

[9] X. Wang, G. Jia, H. Wang et al., "Diameter effects on cytotoxicity of multi-walled carbon nanotubes," Journal of Nanoscience and Nanotechnology, vol. 9, no. 5, pp. 3025-3033, 2009.

[10] P. Wick, P. Manser, L. K. Limbach et al., "The degree and kind of agglomeration affect carbon nanotube cytotoxicity," Toxicology Letters, vol. 168, no. 2, pp. 121-131, 2007.

[11] L. Wang, S. Luanpitpong, V. Castranova et al., "Carbon nanotubes induce malignant transformation and tumorigenesis of human lung epithelial cells," Nano Letters, vol. 11, no. 7, pp. 2796-2803, 2011.

[12] M. Bottini, S. Bruckner, K. Nika et al., "Multi-walled carbon nanotubes induce T lymphocyte apoptosis," Toxicology Letters, vol. 160, no. 2, pp. 121-126, 2006.

[13] P. X. Dong, B. Wan, and L. H. Guo, "In vitro toxicity of acid-functionalized single-walled carbon nanotubes: effects on murine macrophages and gene expression profiling," Nanotoxicology, vol. 6, no. 3, pp. 288-303, 2012.

[14] C. M. Sayes, F. Liang, J. L. Hudson et al., "Functionalization density dependence of single-walled carbon nanotubes cytotoxicity in vitro," Toxicology Letters, vol. 161, no. 2, pp. 135142, 2006.
[15] L. W. Zhang, L. Zeng, A. R. Barron, and N. A. MonteiroRiviere, "Biological interactions of functionalized singlewall carbon nanotubes in human epidermal keratinocytes," International Journal of Toxicology, vol. 26, no. 2, pp. 103-113, 2007.

[16] J. Cveticanin, G. Joksic, A. Leskovac, S. Petrovic, A. V. Sobot, and O. Neskovic, "Using carbon nanotubes to induce micronuclei and double strand breaks of the DNA in human cells," Nanotechnology, vol. 21, no. 1, Article ID 015102, 7 pages, 2010.

[17] A. Albini, V. Mussi, A. Parodi et al., "Interactions of singlewall carbon nanotubes with endothelial cells," Nanomedicine, vol. 6, no. 2, pp. 277-288, 2010.

[18] H. Tong, J. K. McGee, R. K. Saxena, U. P. Kodavanti, R. B. Devlin, and M. I. Gilmour, "Influence of acid functionalization on the cardiopulmonary toxicity of carbon nanotubes and carbon black particles in mice," Toxicology and Applied Pharmacology, vol. 239, no. 3, pp. 224-232, 2009.

[19] R. K. Saxena, W. Williams, J. K. McGee, M. J. Daniels, E. Boykin, and M. I. Gilmour, "Enhanced in vitro and in vivo toxicity of poly-dispersed acid-functionalized single-wall carbon nanotubes," Nanotoxicology, vol. 1, no. 4, pp. 291-300, 2007.

[20] A. Pietroiusti, M. Massimiani, I. Fenoglio et al., "Low doses of pristine and oxidized single-wall carbon nanotubes affect mammalian embryonic development," ACS Nano, vol. 5, no. 6, pp. 4624-4633, 2011.

[21] A. Magrez, S. Kasas, V. Salicio et al., "Cellular toxicity of carbon-based nanomaterials," Nano Letters, vol. 6, no. 6, pp. 1121-1125, 2006.

[22] T. Coccini, E. Roda, D. A. Sarigiannis et al., "Effects of watersoluble functionalized multi-walled carbon nanotubes examined by different cytotoxicity methods in human astrocyte D384 and lung A549 cells," Toxicology, vol. 269, no. 1, pp. 4153, 2010.

[23] A. Patlolla, B. Patlolla, and P. Tchounwou, "Evaluation of cell viability, DNA damage, and cell death in normal human dermal fibroblast cells induced by functionalized multiwalled carbon nanotube," Molecular and Cellular Biochemistry, vol. 338, no. 1-2, pp. 225-232, 2010.

[24] A. K. Patlolla, S. M. Hussain, J. J. Schlager, S. Patlolla, and P. B. Tchounwou, "Comparative study of the clastogenicity of functionalized and nonfunctionalized multiwalled carbon nanotubes in bone marrow cells of Swiss-Webster mice," Environmental Toxicology, vol. 25, no. 6, pp. 608-621, 2010.

[25] K. T. Al-Jamal, H. Nerl, K. H. Müller et al., "Cellular uptake mechanisms of functionalised multi-walled carbon nanotubes by $3 \mathrm{D}$ electron tomography imaging," Nanoscale, vol. 3 , no. 6 , pp. 2627-2635, 2011.

[26] A. K. Patlolla, A. Berry, and P. B. Tchounwou, "Study of hepatotoxicity and oxidative stress in male Swiss-Webster mice exposed to functionalized multi-walled carbon nanotubes," Molecular and Cellular Biochemistry, vol. 358, no. 1-2, pp. 189199, 2011.

[27] A. D. Maynard, P. A. Baron, M. Foley, A. A. Shvedova, E. R. Kisin, and V. Castranova, "Exposure to carbon nanotube material: aerosol release during the handling of unrefined single-walled carbon nanotube material," Journal of Toxicology and Environmental Health, vol. 67, no. 1, pp. 87-107, 2004.

[28] A. A. Shvedova, V. Castranova, E. R. Kisin et al., "Exposure to carbon nanotube material: assessment of nanotube cytotoxicity using human keratinocyte cells," Journal of Toxicology and Environmental Health, vol. 66, no. 20, pp. 1909-1926, 2003. 
[29] S. K. Smart, A. I. Cassady, G. Q. Lu, and D. J. Martin, “The biocompatibility of carbon nanotubes," Carbon N. Y., vol. 44, no. 6, pp. 1034-1047, 2006.

[30] R. R. Mercer, J. Scabilloni, L. Wang et al., "Alteration of deposition pattern and pulmonary response as a result of improved dispersion of aspirated single-walled carbon nanotubes in a mouse model," American Journal of Physiology, vol. 294, no. 1, pp. L87-L97, 2008.

[31] A. A. Shvedova, E. R. Kisin, R. Mercer et al., "Unusual inflammatory and fibrogenic pulmonary responses to singlewalled carbon nanotubes in mice," American Journal of Physiology, vol. 289, no. 5, pp. L698-L708, 2005.

[32] R. R. Mercer, A. F. Hubbs, J. F. Scabilloni et al., "Distribution and persistence of pleural penetrations by multi-walled carbon nanotubes," Particle and Fibre Toxicology, vol. 7, article 28, 2010.

[33] D. Cavallo, C. Fanizza, C. L. Ursini et al., "Multi-walled carbon nanotubes induce cytotoxicity and genotoxicity in human lung epithelial cells," Journal of Applied Toxicology, vol. 32, no. 6, pp. 454-464, 2012.

[34] A. Casey, M. Davoren, E. Herzog, F. M. Lyng, H. J. Byrne, and G. Chambers, "Probing the interaction of single walled carbon nanotubes within cell culture medium as a precursor to toxicity testing," Carbon N. Y., vol. 45, no. 1, pp. 34-40, 2007.

[35] K. Pulskamp, S. Diabaté, and H. F. Krug, "Carbon nanotubes show no sign of acute toxicity but induce intracellular reactive oxygen species in dependence on contaminants," Toxicology Letters, vol. 168, no. 1, pp. 58-74, 2007.

[36] A. Simon-Deckers, B. Gouget, M. Mayne-L'Hermite, N. Herlin-Boime, C. Reynaud, and M. Carrière, "In vitro investigation of oxide nanoparticle and carbon nanotube toxicity and intracellular accumulation in A549 human pneumocytes," Toxicology, vol. 253, no. 1-3, pp. 137-146, 2008.

[37] A. R. Collins, S. J. Duthie, and V. L. Dobson, "Direct enzymic detection of endogenous oxidative base damage in human lymphocyte DNA," Carcinogenesis, vol. 14, no. 9, pp. 17331735, 1993.

[38] A. Jos, S. Pichardo, M. Puerto, E. Sánchez, A. Grilo, and A. M. Cameán, "Cytotoxicity of carboxylic acid functionalized single wall carbon nanotubes on the human intestinal cell line Caco2," Toxicology in Vitro, vol. 23, no. 8, pp. 1491-1496, 2009.

[39] D. Pantarotto, J. P. Briand, M. Prato, and A. Bianco, "Translocation of bioactive peptides across cell membranes by carbon nanotubes," Chemical Communications, vol. 10, no. 1, pp. 1617, 2004. 

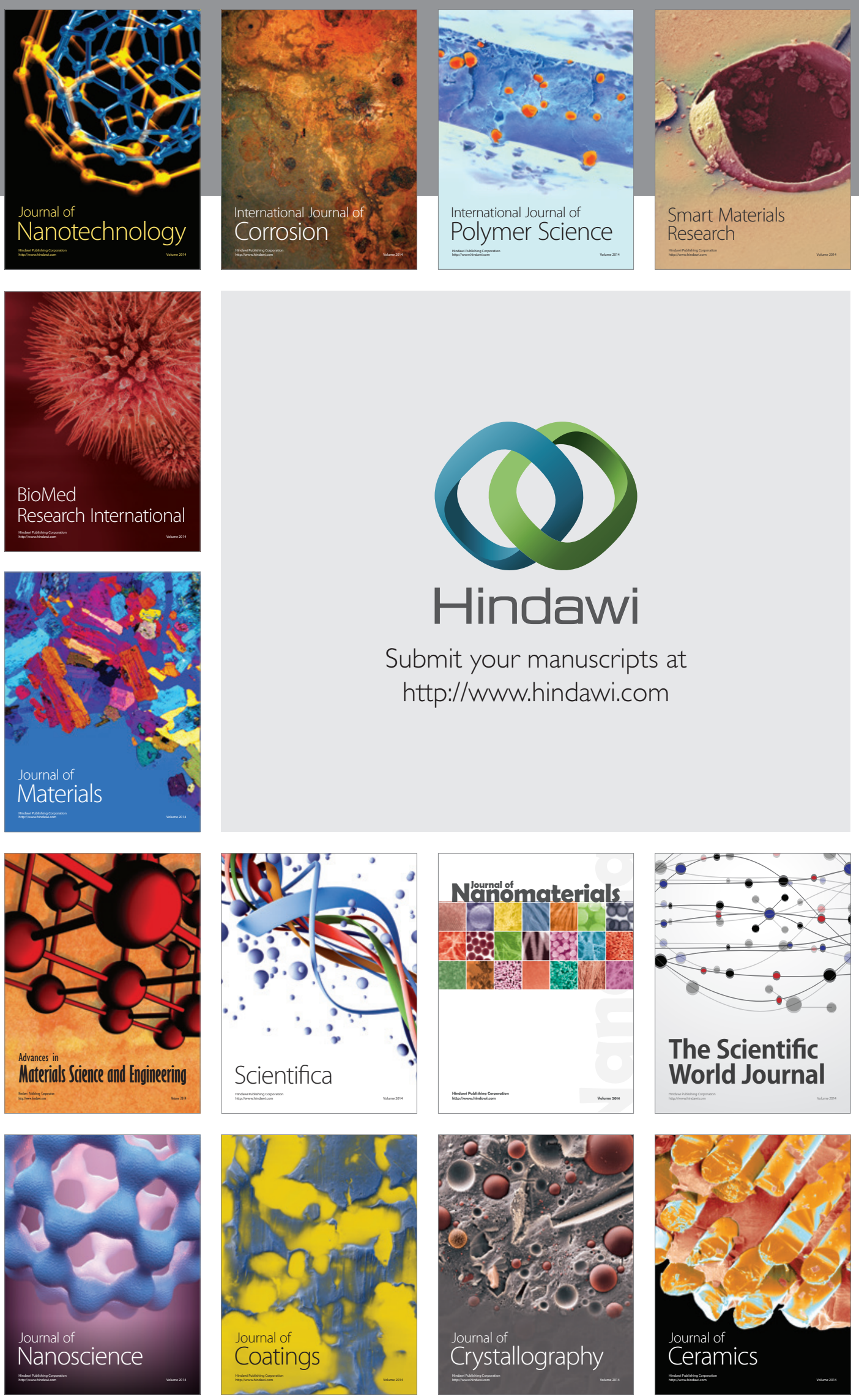

The Scientific World Journal

Submit your manuscripts at

http://www.hindawi.com

\section{World Journal}

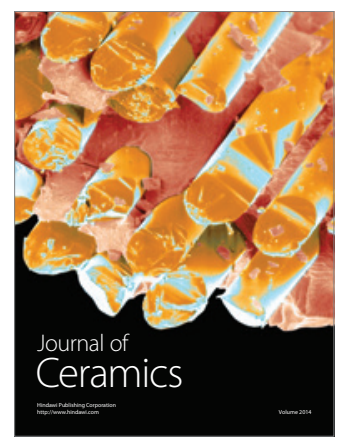

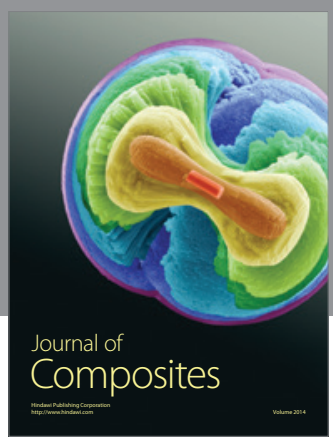
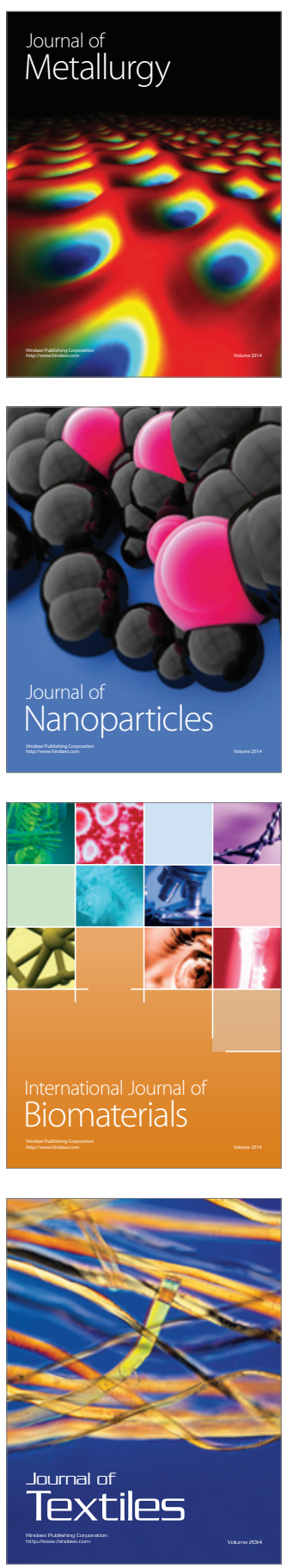